4. Gonin, M.-Nouvelles Observations de Scotome Annulaire dans la Dégénérescence Pigmentaire de la Retina. Aun. d'Ocul., Vol. CXXVII, p. 90, 1902.

5. Greeves, R. A.-Report of a case of Retinitis Pigmentosa with Pathological Investigation. R.L.O.H. Reps., Vol. XVIII, p. 301, 1912.

6. KR ückmanN, E.-Anatomisches ueber die Pigmentepithelzellen der Retina. Arch. f. Ophthal., Bd. XLVII, pt. 3, p. 644, 1899

7. LeBer, T.-Graefe-Saemisch Handb. d. ges. Augenheilk., Vol. VII, p. 1076, 1915.

8. Menner, E.-Untersuchungen ueber die Retina mit besonderer Berücksichtigung der ausseren Körnerschicht ein Beitrag zur Duplizitätstheorie. Zeits.f. Veigl. Physiol., Bd. VIII, p. 761, 1929.

9. Nettleship, E.-On the Distribution of the Choroidal Arteries as a factor in the localization of certain forms of Choroiditis and Retinitis. R.L.O.H. Reps., Vol. XV, pt. 3, p. 189, 1903.

10. Sтоск W.-Ueber eine bis jetzt noch nicht beschriebene Form der familiar auftretenden Netzhautdegeneration bei gleichzeitiger Verblödung und ueber typische Pigmentdegeneration der Netzhaut. Klin. Monatsbl. $f$. Augenheilk., Bd. XLVI, pt. 1, p. 225, 1908.

11. STuder, T. F.-On Pigmentation of the Retina after Optico Ciliary Neurectomy in Man. Arch. of Ophthal., Vol. XXXV, p. 333, 1906.

12. VerhoEFF, F. H.-Microscopic Observations in a case of Retinitis Pigmentosa. Arch. of Ophthal., Vol. V, p. 392, 1931.

13. WAGENMANN, A.-Experimentelle Untersuchungen ueber den Einfluss der Circulation in den Netzhaut und Aderhautgefässen auf die Ernährung des Auges, insbesondere der Retina, und ueber die Folgen der Sehnervendurchschneidung. Arch. f. Ophthal., Bd. XXXVI, pt. 4, p. 1, 1890.

\title{
ANNOTATION
}

\section{National Ophthalmic Treatment Board}

The Annual Report of the National Ophthalmic Treatment Board 1937-38 is now to hand. As in previous reports the work of the Board is dealt with under three main headings, viz., Investigation, Education and Administration of the National Eye Service.

With regard to the incidence of pathological conditions in cases of eye defect an analysis has been made last year of a fourth series of 10,000 cases. In each of these four series the returns have been collated by the same competent statistician, and the record cards upon which the returns have been made have remained unchanged. There has been no selection of cases.

The results are arranged in two tables. These should be studied by everyone concerned but it will be of interest if we give a transcript of Table I. "Cases of error of refraction only (1934) 64.09 per cent., (1935) 64.22 per cent., (1936) 63.59 per cent., (1937) 62.54 per cent.

Cases of error of refraction plus one or more other eye conditions (1934) $29 \cdot 15$ per cent., (1935) $27 \cdot 88$ per cent., (1936) $25 \cdot 83$ per cent., (1937) 28.03 per cent.

Cases without error of refraction, but with one or more 'other 
eye conditions' (1934) 5.75 per cent., (1935) $7 \cdot 36$ per cent., (1936) 7.93 per cent., (1937) 8.69 per cent.

Cases with no appreciable eye defect (1934) 1.0 per cent., (1935) 0.54 per cent., (1936) 0.85 per cent., (1937) 0.75 per cent."

Table 2 gives the details and percentages of such conditions as are likely to appear in any eye examination.

The percentage figures vary only within very narrow limits as a general rule. In dealing with education it is of interest to note that increasing use is being made of propaganda by means of films.

The importance of the work undertaken by the National Ophthalmic Treatment Board can hardly be over emphasised. Its progress may appear to some to be slow but we feel certain that it is sure, and that in the long run it will lead to what is so earnestly desired, the ophthalmic services of the country being under the care of properly qualified ophthalmic practitioners.

\section{ABSTRACTS}

\section{MISCELLANEOUS}

(1) Penman, G. G. and Wolff, E. (London).-Primary tumours of the lacrimal sac. Lancet, p. 1325, June 11, 1938.

(1) Penman and Wolff review the literature of primary neoplasms of the lacrimal sac and comment on their rarity. It seems that carcinoma and sarcoma are the commonest, for out of 64 collected cases there were 24 of the former and 20 of the latter.

They describe a case of epithelial hyperplasia of the lacrimal sac in a man aged 75 years. Histological examination showed that the epithelial cells lining the sac had proliferated and formed many layers and that some metamorphosis from columnar cells to polyhedral cells had occurred. The basement membrane was intact but the authors consider that the neoplasm was on the borderline of malignancy. The lacrimal sac was excised and at operation it was found that the neoplasm and sac had eroded the lacrimal fossa. The bone and nasal mucosa at the site of the lacrimal fossa were removed and the cavity drained into the nose.

In this case it was thought inadvisable to give either $\mathrm{X}$-ray or radium after operation. One year after operation there was no evidence of recurrence.

Neoplasms of the lacrimal sac cause epiphora and some inflammatory changes in the sac wall. The presence of a mucocele and patency of the naso-lacrymal duct renders the swelling partly reducible on pressure.

H. B. Stallard. 